Vol. 9(3), Serial No. 38, July, 2015:139-146

ISSN 1994-9057 (Print)

ISSN 2070-0083 (Online)

DOI: http://dx.doi.org/10.4314/afrrev.v9i3.12

\title{
Building Savings and Investments Culture among Nigerians
}

\author{
Imegi, John C., Ph.D. \\ Department of Banking and Finance \\ Rivers State University of Science and Technology, Port Harcourt \\ Rivers State, Nigeria
}

\&

Okanta, Sunday U., Ph.D.

Department of Accounting and Finance

Federal University Otuoke, Bayelsa State

\begin{abstract}
Many Nigerians today live below the poverty line not necessarily because they have low incomes or poor salaries, but perhaps they lack savings and investments culture. The Harmonized Nigeria Living Standard Survey reports that Nigeria spends about N25 billion daily on food items. There is high propensity to consume but low propensity to save. This is quite alarming for a developing nation. High consumption would mean low savings, low investment, and low capital formation. If this persists, the Nigeria populace will be engulfed in poverty trap. It is therefore necessary to build among Nigerians savings and investments culture. A review of extant literature revealed that people save and invest for several reasons among which are to enhance the standard of living, take advantage of rare business opportunities, and meet unforeseen circumstances. Savings can be done through piggy, stokvel, thrift collection, credits unions, and banking system while investment is in the form of real
\end{abstract}


asset, financial asset, and foreign exchange investment. Whatever form of investment one contemplates, it is very important to assess the risk-return trade off of such investment. Savings and investments guarantee your future. No matter how small is your income, you must learn to save to mobilize funds for investment. If the standard of living of Nigeria populace must be enhanced, there is therefore serious need for household savings and investment. Savings and investments must be our life style. We however in this study recommended the credit unions method of savings for Nigerians who belong to a field of membership.

\section{Introduction}

The Harmonized Nigeria Living Standard Survey of 2009/2010 revealed that the consumption pattern in Nigeria is stewed towards food. Nigeria populace consumes at least $\$ 25$ billion worth of food daily, which represents about $65 \%$ of total expenditure (National Bureau of Statistics, 2012). The less a society spends on food, the more developed the society becomes because the money not spent on consumption is saved to provide the resources that are needed to fund investment (Olusoji, 2003). Smiths (1776) recognized the importance of savings when he observed that capital is increased by parismony and diminished by prodigality and misconduct.

Many Nigerians today live below the poverty line not necessarily because they have low incomes or poor salaries, but because they lack savings and investments culture (Zimbio, 2010). The Department for International DevelopmentDFID (2012) reported that about 34.9 million adults population in Nigeria do not save. The propensity to consume is not in any way comparable to the propensity to save. It is therefore imperative that the Nigeria populace have a re-orientation towards savings and investment for improved standard of living. It is on this premise that we ask the following questions. What is savings and investment? Why do I need to save and invest? How do I save? Where do I save? What kind of investment do I make?

\section{What Is Savings and Investments?}

According to Olusoji (2003), savings represent that part of net income that is not spent on current consumption, but when applied to capital investment output increases. In other words, saving is a sacrifice of current consumption that provides for accumulation of capital. It is the act of preserving income for future use.

On the other hand, investment is the commitment of capital to the purchase of an asset in order to gain profitable returns (Yio, 2014). Investment is the purchase of an asset with the hope that it will generate income or appreciate in the future. It involves committing money into an investment vehicle in the hope of making a financial gain with the possibility of losing it. 
Although some people use savings and investments interchangeably, from the professional point of view, saving is different from investment. A review of literature indicates the following differences:

(1) The purpose of savings is for the security and accumulation of capital while investment is for wealth creation. This implies that your motive for savings is to secure and ensure the safety of your money, whereas your motive for investment is for financial gain.

(2) There is high level of liquidity in savings. This means that you have easy access to your money at any time, but this is not true of investment.

(3) There is no guarantee that you will get your money back when you invest. This implies that there is a high level of risk in investment, but savings risk is low. In most cases savings are risk-free.

(4) When you invest, you have the opportunity to earn more money than when you save. In other words, investment generates greater return than cash left in savings account.

(5) The reason why people find it difficult to save is low income, whereas people find it difficult to invest because of uncertainty of returns. (Dell' Amore, 1983; Modigliani, 1988).

\section{Why Do I Need to Save and Invest?}

According to Anyaele (2003) and Yio (2014), people save and invest for several reasons among which are:

(1) To enhance the standard of living - Savings and investment help people to enjoy the same or higher standard of living particularly when they retire from active service

(2) To acquire assets - Most people save and invest in order to acquire luxurious assets, such as expensive cars, landed property, building etc.

(3) For speculatory purpose - Savings and investments are made with the hope of making money available for future purchases with the expectation that prices of goods and services will fall.

(4) For security purpose - Another reason why people save and invest is to prepare for the rainy day. That is for unforeseen eventualities like retrenchment, sickness, and natural disaster.

(5) To raise more capital - People save and invest so as to accumulate more capital. The more capital is invested the greater the returns. 


\section{How Do I Save?}

In order to be able to save, you must reduce your current consumption on food items. You do not need to have surplus to be able to save. Yanto (2013) recommended that to be financially secure, an individual or household should save at least $10-20$ percent of net income. He however recommended the following strategies for savings.

(1) Every day put all your loose change into a pause or a box. Once in a while deposit the money in your savings account-. With time the money will grow.

(2) In every month, set aside a certain amount of money from your income or salaries for savings. The practice is that after paying all of the bills whatever is left is saved. This strategy of savings doesn't really work because in most cases nothing is left over to save.

(3) Pay yourself first - This is the best strategy for savings. What it means is that you designate a certain amount of your income as your pay and pay that money to yourself before you settle your bills or someone else. This amount may be as little as $\$ 100$ or a certain percentage of your salaries. You can develop an automatic way of doing this. May be, mandating your employer to make deductions of the amount into your savings account.

\section{Where Do I Save?}

The different schemes of savings as identified by Zimbio (2010) and Yio (2014) include:

(1) Piggy - This is a personal home saving scheme whereby people keep money in their cupboard, safe box or under the pillow. This is a very risky way to save money because the money could be stolen or destroyed by fire. Access to the money is not restricted by any means. In those days when the banking system in Nigeria was undeveloped, many Nigerians used to save for Christmas by putting the money in a safe box. But before Christmas, in most cases the safe box is destroyed so as to have access to the money. Unless one is financially disciplined, this is not a wise way to save.

(2) Stokvel - The Stokvel scheme popularly known as Esusu in Eastern Nigeria is another traditional means of saving money. Members usually know each other well and make monthly contributions that are disbursed to individuals in turns often no interest is paid on the savings and it usually runs on a trust basis. There are usually no written agreement and no documentations. In fact there is no legal protection if a member fails to make contributions after taking his or her turn. This method is also called rotational savings and loans scheme (ROSCA). 
(3) Thrift Collection - This method is popularly known as Akawo. It is a daily or week contribution of fixed amount of money in the hands of a well trusted individual or group. The Akawo practitioners usually move around soliciting for collections from those keen on saving. They equally give loans to contributors depending on the amount of money saved. Cases abound where Akawo practitioners disappeared with contributors' money. This makes thrift collection method a risky method of saving.

(4) Credit Unions - Credit union are co-operatives, not-for-profit organizations that exist to serve their members rather than to maximize profit. Credit unions are member-owned and controlled through a board of directors elected by the members. They mobilize savings by collecting deposits from members, make loans and provide a wide array of other services. As member-owned institutions, credit unions focus on providing a safe place to save and borrow at reasonable rates. Unlike banks, credit unions return surplus income to their members in the form of dividend. Credit union is not open to everybody. In order to join a credit union, potential member must be part of a field of membership.

(5) Banking - Banks and other financial institutions such as insurance companies are other means of saving money. To use this method, an individual must open a savings account with a bank and make deposits into the account. It is a safe way to save and grow your money. Interest is paid on the deposit made though at a very low rate. The customer equally has access to soft loan such as overdraft and salary advance through the banking method of saving. Bank failure could cause deposits to be lost as in the case with All States Trust Bank and Savannah Bank. But with the recent reforms in the banking industry in Nigeria, the bank is the safest place to save your money. The problem with the banking method of savings is that there is a high level of bureaucracy in accessing loan facility.

\section{What Kind of Investment Do I Make?}

There are different kinds of investments. These include - real assets investment, financial assets investment, and foreign exchange market investment.

(1) Real Asset Investment - This involves investment in physical assets such as land, buildings, motor vehicle, machineries plant and equipment, etc. It requires huge amount of capital to invest in real assets. This kind of investment has a very low amount of risk, hence its profitability is evaluated in most cases without due consideration to risk. In evaluating the profitability of real asset investment the expected cash inflows have to be estimated using historical analogy, competitive parity etc. Since a naira today worth more 
than a naira tomorrow, the estimated cash inflows have to be discounted to their present values. The discount rate used for such discounting in most cases is the rate of inflation prevailing in the country. The various methods used in evaluating the profitability of investment in real assets include discounted payback, discounted accounting rate of returns, net present value, internal rate of returns, and profitability index. But the riskiness of real asset investment is evaluated using the risk-adjusted discount rate, certainty equivalent, among others (Masa, Imegi and Akenbor, 2012).

(2) Financial Asset Investment - This is concerned with the commitment of money for the purchase of securities such as shares and bonds in the money market and or capital market. Bond instruments are in most cases risk-free and they have short maturity period with fixed rate of interest. Interest is the only reward accruable to bond investors.

But investment in shares involves a high level of risk due to market forces which are unpredictable. The reward for investment in shares is in two-fold, capital appreciation and dividends depending on the ownership status. The capital required for investment in financial assets depends on the number of units of the security one is willing to acquire. In financial assets investment, there is therefore the need for risk-return trade off. Internal rate of returns is used in evaluating the returns of financial asset investment (Yio, 2014). The investment analysis does not end with evaluating its returns'; assessing the riskiness of the investment is of paramount importance. Standard deviation or variance is used in assessing the riskiness of financial asset investment. An investment may have a very good return but if the investment risk is equally very high, it will be irrational to make such investment because investors are generally risk averters. Various theories have been developed in assessing the risk nature of investment in financial assets, such as the modern portfolio theory, and the capital asset pricing theory (Pandey, 1979).

(3) Foreign Exchange Market Investment - This is a foreign market that allows participants to buy, sell, exchange, and speculate on currencies. It is a form of investment where participants speculate on the fluctuating value of currencies between two countries. In foreign exchange market, you can be buying one currency whose value is falling and simultaneously selling another currency whose value is appreciating.

According to Yanto (2013) foreign exchange market investment is not a scam; it is just a market that is primarily set up for insiders that understand it. Foreign exchange market investment is usually done through the internet. If you cannot trade for yourself, you can engage the services of a broker or a market marker to trade for you. Investment in foreign exchange takes various forms, such as forex trading, 
foreign currency future, foreign currency options, foreign bond fund etc. Although investment in foreign currency is quite rewarding, foreign exchange market involves a high degree of risk including the risk of losing your money. It is the most risky form of investment. Therefore before foreign exchange market investment is made, an assessment of risk-return trade off is also very important.

\section{Conclusion and Recommendation}

The importance of savings and investment cannot be overemphasized if there must be improvement in the standard of living of the people. The more cash you have coming in, the more options you have in terms of life style, ability to weather an emergency or economic downturn, and to build a war chest for future investment or business opportunities. Savings and investments guarantee your future. No matter how small is your income, you must learn to save to be able to mobilize capital towards financing investment. Whatever form of investment one contemplates, it is very important to assess the risk-return trade off of such investment either in real assets, financial assets, or foreign exchange. Savings and investments must be our life style to escape the poverty trap.

It is our humble submission to recommend the credit unions' method of savings such as co-operative societies to Nigerians who are part of a field of membership. It is a safe place to save and borrow at a reasonable rate.

\section{References}

Anyaele, J. U. (2003). Comprehensive economics for senior secondary schools. Lagos: A. Johnson Publishers.

Dell'Amore, G. (1983). Household propensitivity to save in Arnaldo, M (Ed.) Mobilization of Household Savings- A tool for development. Finafrica: Milan.

DFID (2011). The engine of development; The Private Sector and Prosperity for poor people. Journal of Policy Modeling; March, 88-96.

Masa, A., Imegi, J. C. \& Akenbor, C. O. (2012). Financial management for business sector. Port Harcourt: Celwil (Nig.) Publishers.

Modigliani, F. (1988). The role of intergenerational transfers and the life-cycle saving in the accumulation of wealth. Journal of Economic Perspective, (2), 68-72.

National Bureau of Statistics (2012).

Olusoji, M. (2003). Determinants of private savings in Nigeria. NDIC Quarterly, 4549.

Pandy, I. M. (1979). Financial management. New Delhi: Vikas Publishers. 
Smith, A. (1776). An enquiry into the nature and causes of wealth of nations. Glasgows: University of Glasgows Press.

Yanto, J. (2013). Investment handbook. New York: Richard D. Irwin.

Yio, C. R. (2014). Risk analysis in financial asset investment. http:www.googlebook.com. Downloaded on 12th May, 2015.

Zimbio, O. (2010). Financial barometer for poverty. Johannesburg: Global Publications. 